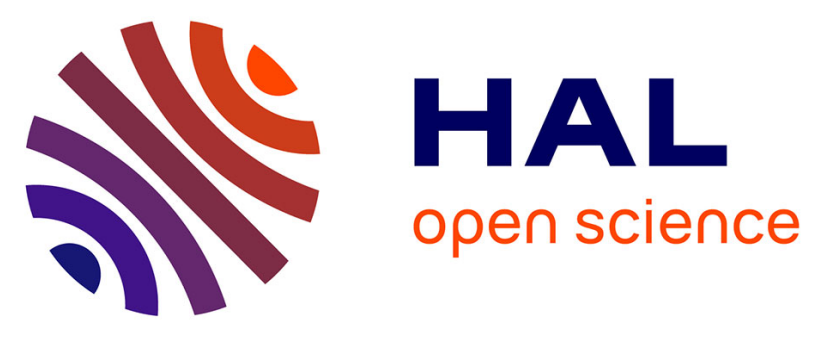

\title{
Diarrheic shellfish poisoning due to toxic mussel consumption: first recorded outbreak in Greece
}

Chrissanthy Vassilios Papadopoulou, Vangelis Economou, Moira Brett, Athina Kansouzidou, George Filioussis, Kostas Charalabopoulos

\section{To cite this version:}

Chrissanthy Vassilios Papadopoulou, Vangelis Economou, Moira Brett, Athina Kansouzidou, George Filioussis, et al.. Diarrheic shellfish poisoning due to toxic mussel consumption: first recorded outbreak in Greece. Food Additives and Contaminants, 2007, 24 (03), pp.297-305. 10.1080/02652030601053139 . hal-00577520

\section{HAL Id: hal-00577520 \\ https://hal.science/hal-00577520}

Submitted on 17 Mar 2011

HAL is a multi-disciplinary open access archive for the deposit and dissemination of scientific research documents, whether they are published or not. The documents may come from teaching and research institutions in France or abroad, or from public or private research centers.
L'archive ouverte pluridisciplinaire HAL, est destinée au dépôt et à la diffusion de documents scientifiques de niveau recherche, publiés ou non, émanant des établissements d'enseignement et de recherche français ou étrangers, des laboratoires publics ou privés. 


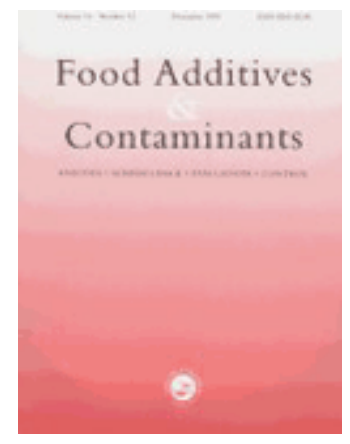

\section{Diarrheic shellfish poisoning due to toxic mussel consumption: first recorded outbreak in Greece}

\begin{tabular}{|r|l|}
\hline Journal: & Food Additives and Contaminants \\
\hline Manuscript ID: & TFAC-2006-039.R1 \\
\hline Manuscript Type: & Original Research Paper \\
\hline Author: & O6-Oct-2006 \\
\hline Complete List of Authors: & $\begin{array}{l}\text { Papadopoulou, Chrissanthy; Ioannina University, Medical School, } \\
\text { Microbiology; Medical School, Microbiology } \\
\text { ECONOMOU, VANGELIS; Medical School, Microbioloyg } \\
\text { Brett, Moira; CPHLS, Food Microbiology } \\
\text { KANSOUZIDOU, ATHINA; Hospital for Infectious Diseases, Clinical } \\
\text { Microbiology } \\
\text { FILIOUSSIS, GEORGE; Medical School, Microbiology } \\
\text { CHARALABOPOULOS, KOSTAS; Medical School, Physiology }\end{array}$ \\
\hline Methods/Techniques: & Microbiology \\
\hline Additives/Contaminants: & Environmental contaminants \\
\hline Food Types: & Fish and fish products \\
\hline & \\
\hline
\end{tabular}

\section{SCHOLARONE Manuscripts}




\section{Diarrheic shellfish poisoning due to toxic mussel consumption: first}

\section{2 recorded outbreak in Greece}

3

4 V. ECONOMOU1', C. PAPADOPOULOU ${ }^{1}$, M. BRETT ${ }^{2}$, A. KANSOUZIDOU ${ }^{3}, \mathrm{~K}$. 5 CHARALABOPOULOS $^{4}$, G. FILIOUSSIS ${ }^{1}$, and K. SEFERIADIS ${ }^{5}$

6

$7 \quad{ }^{1}$ Food Microbiology Unit, Microbiology Department, Medical School, University of 8 Ioannina, loannina, 45110, Greece

9

$10{ }^{2}$ Marine Biotoxins Unit, Food Safety Microbiology Laboratory, Central Public Health 11 Laboratory Service, 61 Colindale Avenue, London NW9 5HT, UK 12

$13{ }^{3}$ Clinical Microbiology Laboratory, Hospital for Infectious Diseases, G. Labraki Street, 14 Thessaloniki, Greece

15

$16{ }^{4}$ Deparment of Physiology, Clinical Unit, Medical School, University of Ioannina, Ioannina, 1745110, Greece

18

$19{ }^{5}$ Clinical Chemistry Department, Medical School, University of Ioannina, Ioannina, 45110 , 20 Greece

$23{ }^{*}$ Corresponding author- Chrissanthy Papadopoulou, e-mail: cpapadop@cc.uoi.gr 


\section{Abstract}

2

3 During the week $14-20^{\text {th }}$ January 2000,120 people visited the Emergency Departments of

4 Thessaloniki (Northern Greece) hospitals complaining of acute gastrointestinal illness

5 after eating mussels (Mytilus galloprovincialis). The symptoms indicated diarrhoeic

6 shellfish poisoning and the toxicity of mussels harvested from Thermaikos Gulf in

7 Thessaloniki during the outbreak, was investigated using mouse bioassays. The

8 bioassays revealed toxicity to mice by the mussel samples, while high numbers of toxic

9 algae Dinophysis acuminata were identified in water samples from Thermaikos Gulf.

10 Harvesting of mussels was immediately suspended and a monitoring programme for algal

11 blooms was established from then onwards. During a follow-up of the mussels' toxicity

12 from January 2000 through January 2005, two more mussel samples were found positive

13 for DSP, one harvested in March 2001 from the area of the outbreak (Thermaikos Gulf)

14 and one harvested in January 2001 from North-western Greece (Amvrakikos Gulf).

15 However, no sporadic cases or outbreaks were reported during this period.

16

17 Keywords: Diarrheic Shellfish Poisoning, Greece, mussels, algal toxins, Dinophysis, 18 outbreak 


\section{Introduction}

3 Diarrheic shellfish poisoning (DSP) is a toxic syndrome caused by the ingestion of 4 shellfish contaminated with algal toxins produced by marine dinoflagellates belonging to

5 Dinophysis spp. (D. fortii, D. acuta, D. acuminata, D. caudate, D.hastate, D. mitra, $D$. 6 rotundata, D. tripos) (Hallegraef 1997; Yasumoto 2000) and Prorocentrum spp. (P. lima, 7 P. maculosum, P. concavum and P. hoffmianum) (Van Dolah 2000). The DSP toxins 8 belong to a group of fat-soluble polyether compounds, including Okadaic acid (OA) and 9 the closely related Dinophysistoxins (DTX). Gastrointestinal effects have only been 10 proven for OA, DTX-1 and DTX-3 (Murata et al. 1982; Rossini 2000; Vale and Sampayo 11 2002). DTXs are lipophilic and accumulate in the fatty tissue of shellfish. The toxin profiles 12 in shellfish display considerable seasonal and geographical variation (Yasumoto et al. 13 1985; Sechet et al. 1990). Ordinary cooking processes do not destroy DSP toxins (Gestal 14 - Otero 2000).

16 DSP symptoms include diarrhoea, nausea, vomiting, abdominal pain and chills, which 17 manifest within 30 min to a few hours after consumption of contaminated shellfish and 18 persist for 3 to 4 days (Aune and Yndestad 1993). Although short-term effects are 19 relatively mild, long-term effects are more severe and chronic exposure may promote 20 tumour formation in the digestive system (Hallegraef 1997; Rossini 2000). OA and DTX1 21 are potent inhibitors of protein phosphatases and this mode of action may be linked to the 22 observed diarrhoea, degenerative changes in the absorptive epithelium of the small 23 intestine and tumour development (Hallegraef 1997). 
1 DSP was first reported in the Netherlands in the 1960s and in Japan in the late 1970s (Kat

2 1985; Yasumoto et al. 1980). Since then it has been recorded in several European 3 countries including France (van Egmond et al. 1993), Norway (Rossebo et al. 1973;

4 Underdal et al. 1985, Torgersen et al. 2005), Sweden (Krogh et al. 1985), Spain (Campos 5 et al. 1982; Fernández et al. 1996), Italy (Viviani et al. 1995; Ciminiello et al. 1997), 6 Portugal (Vale and Sampayo 1999), Belgium (De Schrijver et al. 2002) former USSR 7 (Konovalova 1993). There are also reports from Japan (Yasumoto et al. 1984; Yasumoto 8 et al. 1985; Yasumoto 2000; Kawabata 1989), India (Karunasagar et al. 1989), Australia, 9 New Zealand, Thailand, North and South America (Hallegraef 1997; Scoging 1998; Gestal 10 - Otero 2000). From the available literature it is concluded that DSP or the presence of 11 DSP toxins in mussels, is increasingly reported particularly in Europe (Table I). The 12 increased reporting may be the result of increasing knowledge and awareness about toxic 13 shellfish poisonings (DSP, ASP and PSP) and the implementation of 14 surveillance/monitoring programmes. Also, it has to be emphasized that toxin producing 15 algae and toxic mollusks are reported from new areas, but well documented cases in 16 Europe are rare and this may be attributed to under-diagnosis and/or underreporting. The 17 shellfish most frequently implicated in DSP are mussels, but it has also been reported 18 from scallops, clams, cockles, oysters and crabs (Gestal - Otero 2000; Vale and 19 Sampayo 2002; Jørgensen et al. 2005; Torgersen et al. 2005). In the present paper the 20 first DSP outbreak in Greece is reported, together with the laboratory findings from mussel 21 samples collected during the outbreak and the subsequent four years after the outbreak. 


\section{Materials and methods}

2 The DSP outbreak investigation

3 During the week $14-20^{\text {th }}$ January, 2000 , one hundred and twenty people of both sexes,

4 aged from 8 to 70 years old, visited the Emergency Departments of the hospitals in the 5 city of Thessaloniki (Northern Greece), suffering from acute non-febrile gastro-enteritis 6 (Table II). The predominant symptoms reported by the patients were diarrhea, nausea, 7 vomiting, abdominal cramps and chills, which persisted for more than $24 \mathrm{~h}$. All patients 8 reported onset of symptoms within $30 \mathrm{~min}$ to $10 \mathrm{~h}$ after consuming a mussel meal (deep 9 fried mussels, poached in cheese and tomato hot sauce, mussel pilaf and cooked mussel 10 salads) in various establishments (restaurants, taverns, homes) within the Greater 11 Thessaloniki area. All the hospitalized patients recovered completely within 12 to $36 \mathrm{~h}$ 12 after the administration (i.v) of saline solution and were completely asymptomatic upon 13 exit from the hospital. [Insert Table II about here]

15 Fecal samples from the hospitalised patients were examined for routine bacterial, viral 16 and parasitic agents causing non febrile gastroenteritis, but they were found negative. The 17 common history of the patients (reporting a mussels' meal), based on relative 18 questionnaires, combined with the clinical and laboratory findings were indicative of 19 diarrheic shellfish poisoning, thus the Veterinary Authorities were immediately notified 20 and consumption of mussels was banned until further notice. Mussel dishes are very 21 popular in the coastal areas of Greece, especially in the vicinity of Thessaloniki and 22 accordingly it was estimated that the actual number of people infected was actually much 23 larger than the 120 cases recorded at the hospitals' admissions desks. Hence, the 24 estimates were for a few hundreds of people infected, who either visited privately a 
1 general practitioner or asked no medical assistance because their symptoms soon

2 subsided.

4 The patients who had prepared their meals at home reported purchase of fresh mussels

5 from seafood retails, supermarkets and open markets in the Thessaloniki greater area

6 and similar retail sources were reported by the restaurant and tavern owners. The fresh

7 mussels (Mytilus galloprovincialis) sold in the markets of Thessaloniki area and in most

8 markets in Northern and Northwestern Greece are harvested from aqua cultures located

9 into the Thermaikos Gulf (Figure 1).

10

11 The Veterinary and Sea Biology authorities reported numbers of dinoflagellates ranging 12 from $3 \times 10^{4}$ to $5,4 \times 10^{4}$ cells/L of the toxic genus Dinophysis spp. in the seawater samples 13 from Thermaikos Gulf, and specifically of the species $D$. acuminata and $D$. sacculus 14 (Koukaras and Nikolaidis 2002). No other episodes either of sporadic cases or outbreaks 15 associated with consumption of mussels exposed to toxin-producing Dinoflagellates of the 16 DSP type have been reported for the following four years, although the presence of toxic 17 Dinophysis acuminata was reported again in Thermaikos Gulf in March - May 2001 18 (Koukaras and Nikolaidis 2002). However, suspension of harvesting and withdrawal of 19 mussels from the market are being applied sporadically in Thermaikos Gulf, whenever 20 algal blooms are detected during the phytoplankton monitoring program, which has been 21 established after the outbreak. An algal bloom is a rapid increase in the population of 22 phytoplankton algae in an aquatic system. The appearance of Dinophysis, even at low 23 densities such as 200 cells per litre, can cause already a toxification of shellfish that is 24 enough to affect humans (Van Egmond et al. 2004). According to the Greek Veterinary 


\section{1}

1 and Sea Biology authorities, seafood harvesting is suspended when toxic dinoflaggelate

2 counts are higher than 200 cells/L.

4 The mussel toxicity investigation

\section{Collection of mussel samples}

6 From January 2000 to January 2005, 36 batches (500 g each) of fresh mussels were 7 examined for DSP toxins contamination. The mussel samples (species Mytilus 8 galloprovincialis) were randomly collected from local seafood markets. Twenty samples 9 were collected from Thermaikos Gulf (Halastra) in Thessaloniki (Northern Greece) and 10 sixteen samples from Amvrakikos Gulf (Preveza) (Northwestern Greece) (Figure 1). 11 [Insert Figure 1 about here] Two out of the 36 samples were sent to the Food 12 Microbiology Unit of the Microbiology Department; University of loannina from colleagues 13 at the Hospital for Infectious Diseases in Thessaloniki during the DSP outbreak. These 14 samples were harvested from the Halastra area of Thermaikos gulf at the 20 January 15 2000. Samples after April 2001 until January 2005 were collected every 3 months. All 16 fresh mussel samples forwarded to our lab were deep-frozen $\left(-30^{\circ} \mathrm{C}\right)$ immediately after 17 collection and were transported by airplane (flight duration $40 \mathrm{~min}$ ) in well insulated boxes 18 to the Food Microbiology Unit, within less than 24 hours after collection and upon arrival 19 were stored at $-30^{\circ} \mathrm{C}$ until testing. The samples were tested within 7 days time after their 20 arrival in our laboratory. The samples were defrosted at room temperature and were 21 thoroughly cleaned under a stream of tap water after external materials were brushed off 22 the shells. From each sample, $200 \mathrm{~g}$ of flesh was homogenized in a blending mixer and a 23 portion of $100 \mathrm{~g}$ was weighed using an Ohaus model 1500D balance (Ohaus Co, P.O. 24 Box 2033 19A Chapin Road Pine Brook, NJ 07058) prior to extraction. 
Extraction of DSP toxins

2 The extraction of DSP toxins was performed following the method validated by the Marine

3 Laboratory, Aberdeen, UK, which is the EU designated UK National Reference Laboratory

4 (NRL) for Marine Biotoxins. The method is that of Yasumoto et al (Yasumoto et al. 1984)

5 with slight modifications. A portion of $100 \mathrm{~g}$ of homogenized mussel flesh was suspended

6 three times and thoroughly mixed with $100 \mathrm{ml}$ of acetone (Scharlau, Analar grade) at

7 room temperature. The aliquots were centrifuged at 3000 rpm for $10 \mathrm{~min}$ in a Sorvall GLC-

84 desktop centrifuge and the supernatants were collected and pooled. Acetone was

9 removed by rotary evaporation for $1 \mathrm{~h}$ at $60^{\circ} \mathrm{C}$ or until all trace of acetone had gone. An

10 Eyela type $\mathrm{N}$ rotary evaporator (Eyela Co, 3-3-4 Honcho Nihonbashi, Chuo-ku, Tokyo 11 103-0023, Japan) was used. The remaining aqueous-lipid extract was separated with 12 diethyl ether (Scharlau, Analar grade), backwashed with a small volume of water and 13 dried by rotary evaporation at $65^{\circ} \mathrm{C}$ for 2 to $4 \mathrm{~h}$. The remaining material was suspended in $144 \mathrm{ml}$ of $1 \%$ Tween 60 (Merck) aqueous solution.

16 Mouse bioassay

17 BALB-C strain white mice weighting 19 to $21 \mathrm{~g}$ each were used for the mouse bioassay. 18 The mice were weighed prior to intra-peritoneal injection of $1 \mathrm{ml}$ of the mussel extract. 19 Three mice were used for each sample. All injected mice and controls were monitored for 20 a period of at least $24 \mathrm{~h}$ after injection. Initially the mice were observed constantly for the 21 first $6 \mathrm{~h}$ and from then every $1 \mathrm{~h}$ for the remaining $18 \mathrm{~h}$. During the $24 \mathrm{~h}$ monitoring any 22 behavioral changes or symptoms were recorded in detail. When no typical symptoms of 23 DSP intoxication were observed after $24 \mathrm{~h}$, the mice were monitored for an additional $24 \mathrm{~h}$ 24 period. The symptoms that were characterized as typical of DSP intoxication were initial 25 apathy, general weakness, difficulty in movement, spasms, contractions, bluish skin 

1

1 coloration and respiratory distress and death. According to the Decision 2002/225/EC,

2 death of two out of three mice within 24 hours after inoculation into each of them of an

3 extract equivalent to $5 \mathrm{~g}$ of hepatopancreas or $25 \mathrm{~g}$ whole body should be considered as a

4 positive result for the presence of one or more of the toxins mentioned, when a mouse

5 bioassay is utilized as a screening method.

6

\section{Results and discussion}

8 During this investigation positive mouse bioassay results were obtained in 4 out of 36

9 samples tested. Specifically, 3 samples out of 9 collected from the area of Halastra within 10 a two-year period from the onset of the DSP outbreak were found positive by the mouse 11 bioassay method. The two samples collected during the outbreak were toxic resulting in 12 death of mice within $85-90$ min after the intra-peritoneal injection. The third positive 13 sample harvested from the area of Halastra was collected 15 months after the outbreak 14 when the mussel withdrawal was recalled. However, no sporadic cases or outbreak due to 15 DSP or similar gastrointestinal illness in humans were recorded during the period the DSP 16 positive sample was collected.

18 The fourth positive sample was harvested from the Amvrakikos Gulf in Northwestern 19 Greece, where no positive or suspect DSP cases have ever been recorded. Amvrakikos 20 Gulf is the nearest to loannina and like Thermaikos, it is shallow, calm, warm and thought 21 to be the most polluted gulf in the Ionian Sea, which is part of the Adriatic Sea, where 22 there are frequent reports for toxic blooms (Boni et al. 1990; Fatorruso et al. 1992; Draisci 23 1995; Viviani et al. 1995; Ciminiello et al. 1997; 1998; Caroppo et al. 2001; Pavela 24 Vranic et al. 2002). Also, it should be noted that the mice injected with the extract of the 25 Amvrakikos sample, in addition to the typical DSP intoxication symptoms, exhibited a 
1 marked hypersensitivity $2 \mathrm{~h}$ prior to death, together with convulsions. The symptoms of

2 the mice following intraperitoneal injection are presented in Table III. [Insert Table III

3 about here]

4

5 There are a number of studies from different countries concerning DSP outbreaks, 6 sporadic cases or detection of toxins in a variety of seafood (Table I). The DSP outbreak 7 described in this paper is the first recorded in Greece and it was classified as a diarrheic 8 shellfish poisoning, based on clinical manifestations characteristic for DSP, the common 9 history of all patients reporting consumption of mussels, the absence of any known 10 pathogen in fecal and blood samples from all hospitalized patients, no detection of 11 antibodies to known pathogens, the subsequent analysis of mussels collected during the 12 outbreak and the detection of Dinophysis acuminata in the water of Thermaikos Gulf. The 13 actual number of the people affected cannot be precisely estimated, due to lack of 14 sufficient data. However, the number of 120 people needing urgent medical care within a 15 period of less than 7 days indicates a foodborne outbreak, of the group of seafood-borne 16 emerging diseases, the first recorded in Greece. . [Insert Table I about here]

18 The mouse bioassays performed during the outbreak are indicative of the presence of 19 lipophilic toxins. This finding combined with the increased concentration of $D$. acuminata 20 (Koukaras and Nikolaidis 2002), which is the most common DSP producing species in 21 Europe (Kumagai et al. 1996; Morono et al. 2002), indicates okadaic acid and / or DTX as 22 the potential cause of this outbreak. It should be noted that the third positive sample from 23 Thermaikos Gulf was collected in March 2001 when, according to other researchers 24 (Koukaras and Nikolaidis 2002) an increased number of Dinophysis spp. was observed. 25 Furthermore, the predominant DSP toxins detected in European mussels and especially 
1 in the mussels of the Adriatic Sea are okadaic acid and DTX - 2 (Draisci 1995; Pavela -

2 Vranic et al. 2002). In a recent publication (Ciminiello et al. 2005) concerning 3 investigation of the toxin profile of Greek mussels $M$. galloprovinciallis by Liquid

4 Chromatography - Mass Spectrometry, the presence of okadaic acid only (at levels 0.10 $5-0.20 \mu \mathrm{g} / \mathrm{g})$ is confirmed. The hypersensitivity and the convulsions observed in mice 6 injected with the extract of the positive sample form Amvrakikos gulf, is indicative of the 7 simultaneous presence of an unknown lipophilic toxin along with okadaic acid and / or 8 DTX -2 . Jumping before death, convulsions and short survival time is observed when 9 mice are injected i.p. with yessotoxin (Ciminiello et al. 1997). Although the presence of 10 yessotoxin in mussels has been reported in neighboring areas, it is quite improbable that 11 yessotoxins are the cause of these symptoms. Yessotoxins are poorly soluble in diethyl 12 ether and therefore probably could not co-elute with the other toxins (Ciminiello et al. 13 1997). Another possible explantation for the observed symptoms in this sample is that it 14 contained azaspiracid. After intraperitoneal injection of azaspiracid, mice exhibit 15 respiratory difficulties, spasms, paralysis of the limbs and death (Ito et al. 2000). Still, the 16 presence of azaspiracid has not been proven by analytical methods in shellfish harvested 17 from the Mediterranean Sea (James et al. 2004).

19 Detection of DSP is routinely based on mouse bioassays, HPLC methods and 20 immunoassays. It is generally acknowledged that biological tests suffer from considerable 21 variability and lack of sensitivity and because of increasing opposition to animal testing 22 many efforts have been made to detect DSP toxins by HPLC based methods. However, 23 the lack of availability of analytical standards and Certified Reference materials for all of 24 the DSP toxins currently precludes the sole use of chemical methods in routine monitoring 25 programmes. Additionally, the maximum level for DSP toxins set by regulatory authorities 
1 varies considerably from country to country. In general, levels of DSP toxins greater than

$2200 \mathrm{ng} / \mathrm{g}$ in shellfish are considered dangerous for human consumption (Hallegraef,

3 1997). The potential public health risks and the expanding geographical distribution of the

4 causative dinoflagellates have resulted in the issuing by the Commission of the European

5 Countries of the Decision 2002/225/EC of the 15 May 2002, which is an amendment of

6 the Council directive 91/492/EEC, which states that the maximum level of okadaic acid,

7 dinophysistoxins and pectenotoxins together, in bivalves intended for human consumption

8 (the whole body or any part edible separately) shall be $160 \mu \mathrm{g}$ of okadaic acid

9 equivalents/kg.

10

11 To date, control measures to protect human health against DSP contaminated seafood 12 involve both biological and chemical procedures. At the time of the outbreak in the Food 13 Microbiology Unit we were able to apply only the biological method (mouse bioassay). 14 The accumulation of algal toxins is one of the most critical problems in bivalve 15 aquaculture. Amongst the three most important categories of shellfish poisoning 16 (amnesic, diarrhoeic, paralytic), DSP is the least severe causing only gastrointestinal 17 symptoms. However, the accumulation of toxic algae in many bivalve producing areas has 18 a great economic impact as their appearance leads to the implementation of long term 19 bans on shellfish harvest, which is happening frequently at Thermaikos Gulf aquacultures 20 since the reported outbreak. The factors influencing the growth of the microalgal 21 population include: a) changes in water temperature favoring encysting or excysting of 22 dinoflagellates, b) decreased water salinity, c) increased concentrations of organic 23 substances, d) extended duration of sunlight and e) calm waters (Gestal - Otero 2000; 24 Caroppo et al. 2001). 
1 All these factors are present in Thermaikos Gulf (North Aegean Sea), especially in the

2 Halastra site, where the constantly calm and warm waters favor mussel cultures.

3 However, the outfall of three large rivers in the gulf (Gallikos, Loudias and Axios), the

4 waste effluents of Greater Thessaloniki area (second largest city of Greece) and the

5 drainage of the plain of Central Macedonia (a plain with intensive agricultural activities),

6 make Thermaikos Gulf, ideal aquatic environment for the growth of microalgal population

7 and possible toxin production by dinoflagellates. Similar conditions exist at Amvrakikos

8 Gulf (North Ionian Sea), which is part of the South-central Adriatic Sea. Red tide blooms

9 are known to occur in the central Adriatic Sea since the 80's (Boni et al. 1990). However, 10 toxic blooms associated with shellfish intoxication are becoming more frequent during the 11 last decade in this geographic area (Fattorusso et al. 1992; Viviani et al. 1995; Draisci et 12 al. 1995; Ciminiello et al. 1997; Ciminiello et al. 1998; Draisci et al. 1999; Caroppo et al. 13 2001; Pavela - Vranic et al. 2002).

15 DSP intoxication is still an under reported illness, which is attracting interest after 16 notification of outbreaks (Gestal - Otero 2000; Yasumoto 1985; Vale and Sampayo 2002).

17 Therefore knowledge of its existence along with the recently increasing reports of red tide 18 blooms spreading from Europe to America to Australia should trigger a constant 19 awareness for this emerging seafood zoonotic disease.

\section{Acknowledgments}

22 The present study was carried out during a bilateral joint research project on Marine 23 Biotoxins, participating the Biotoxins Unit, Food Safety Microbiology Laboratory, CPHLS, 24 London UK and the Food Microbiology Unit, Microbiology Department, Medical School, 25 University of Ioannina, GR; the joint project was financially supported by grants from the 
1 General Secretariat for Research and Technology, The Greek Ministry of Development

2 and The British Council. Also the authors wish to thank the former Director of the Clinical

3 Microbiology Laboratory, Hospital for Infectious Diseases, Dr. V. Daneilides for collecting 4 and sending the two mussel samples during the outbreak. Mouse bioassays comply with 5 the current laws of Greece for laboratory animal experimentations.

6

7 References

8

9 Anonymous 1994. Diarrhetic shellfish poisoning associated with mussels. CDR Wkly 4 $10 \quad(22): 101$.

11 Anonymous 1997. An outbreak of diarrhetic shellfish poisoning. CDR Wkly 7 (28): 247.

12 Aune T, Yndestad M. 1993. Diarrhetic shellfish poisoning. Chapter 5. In: Falconer IR, 13 editor. Algal Toxins in Seafood and Drinking Water. London, UK, Academic Press. p. $14 \quad 87-104$

15 Boni L, Mancini L, Milandri A, Poletti R, Pompei M, Viviani R. 1990. First cases of DSP in 16 the Northern Adriatic Sea. International Conference Regione Emilia Romagna; 1990 17 March 21-24; Bologna. Italy.

18 C.E.C. Report of the Scientific Veterinary Committee (Section Public Health) on 19 Diarrhoetic Shellfish Poisoning in Europe. 1990. VI/6182/89-EN Rer.2.

20 Campos MJ, Fraga S, Marino J, Sanchez FJ. 1982. Red tide monitoring program in NW 21 Spain. Report of 1977-1981, International Council for the Exploration of the Sea, 22 Council Meeting (ICES.CM), 1982/L: 27.

23 Carmody EP, James KJ, Kelly SS. 1996. Dynophysistoxin-2 the predominant Diarrhoetic 24 Shellfish toxin in Ireland. Toxicon 34:351-359. 
1 Caroppo C, Congestri R, Bruno M. 2001. Dynamics of Dynophysis sensu lato species

(Dinophyceae) in a coastal Mediterranean environment (Adriatic Sea). Continental Shelf Research 21: $834-1854$.

Ciminiello P, Fattorusso E, Forino M, Magno S, Poletti, R, Satake M, Viviani R, Yasumoto T. 1997. Yessotoxin in mussels of the Northern Adriatic Sea. Toxicon, 35: $177-183$.

Ciminiello, P., Fattorusso, E., Forino, M., Magno, S., Poletti, R., and Viviani, R. 1998. Isolation of Adriatoxin, a new analogue of yessotoxin from mussels of the Adriatic Sea. Tetrahedron Letters, 39: 8897 - 8900.

Ciminiello P, Dell'Aversano C, Fattorusso E, Forino M, Magno S, Santelia F, Tsoukatou M. 2005. Investigation of the toxin profile of Greek mussels Mytilus galloprovincialis by liquid chromatography—mass spectrometry. Toxicon 47: 174 - 181.

De Schrijver K, Maes I, De Man L, Michelet J. 2002. An outbreak of diarrhoeic shellfish poisoning in Antwerp, Belgium. Eurosurveillance, 7:139 - 141.

Dickey RW, Fryxell GA, Granade HR, Roelke D. 1992. Detection of the marine toxins Okadaic acid and Domoic acid in shellfish and phytoplankton in gulf of Mexico. Toxicon 30:355-359.

Draisci R, Lucentini L, Giannetti L, Boria P, Stacchini A. 1995. Detection of diarrheic shellfish toxins in mussels from Italy by ion spray liquid chromatography - mass spectrometry. Toxicon, 33:1591-1603.

Draisci R, Ferretti E, Palleschi L, Marchiafava C, Poletti R, Milandri A, Ceredi A, Pompei M. 1999. High levels of yessotoxin in mussels and presence of yessotoxin and homoyessotoxin in dinoflagellates of the Adriatic Sea. Toxicon 37:1187 - 1193.

Fattorusso E, Ciminiello P, Constantino V, Magno S, Mangoni A, Poletti R, Pompei M, Viviani R. 1992. Okadaic acid in mussels of Adriatic Sea. Marine Pollution Bulletin 24: $234-237$. 
1 Fernández ML, Míguez A, Cacho E, Martínez A. 1996. Detection of Ocadaic acid esters in the hexane extracts of Spanish mussels. Toxicon, $34: 381-387$.

3 Garcia C, Mardones P, Sfeir A, Lagos N. 2004. Simultaneous presence of Paralytic and

Diarrheic Shellfish Poisoning toxins in Mytilus chilensis samples collected in the Chiloe Island. Biological Research 37 supl. A: $721-731$.

6 Gestal - Otero JJ. 2000. Nonneurotoxic toxins. In: Botana LM, Editor. Seafood and freshwater toxins: pharmacology, physiology and detection. New York. Marcel Dekker. p. $45-64$,

Hallegraef GM. 1997. Algal toxins in Australian shellfish. In: Hocking AD, Arnold G, Jenson I, Newton K, Sutherland P, editors. Foodborne microorganisms of Public Health significance $5^{\text {th }}$ Edition. Sydney. AIFST (NSW branch). p. $561-571$.

Ito E, Satake M, Ofuji K, Kurita N, McMahon T, James K, Yasumoto T. 2000. Multiple organ damage caused by a new toxin azaspiracid, isolated from mussels produced in Ireland Toxicon, 38: 917 - 930.

James KJ, Fidalgo Sàez MJ, Furey A, Lehane M. 2004. Azaspiracid poisoning, the foodborne illness associated with shellfish consumption. Food Additives and Contaminants, 21 (9): $879-892$.

Jørgensen K, Scanlon S, Jensen LB. 2005. Diarrhetic shellfish poisoning toxin esters in Danish blue mussels and surf clams. Food Additives and Contaminants, 22 (8):743 $-751$

Karunasagar I, Segar K, Karunasagar I. 1989. Incidence of DSP and DSP in shellfish along the coast of Karnataka state (India). In: Okaichi T, Anderson DM, Nemoto T, editors. Red Tides: Biology, Environmental Science and Toxicology. Elsevier, Amsterdam. p. $61-64$ 
1 Kat M. 1985. Dinophysis acuminata blooms, the distinct cause of Dutch mussel poisoning.

In: Anderson DM, White AW, Baden DG, editors. Toxic dinoflagellates. Elsevier, Amsterdam. p. $73-77$,

Kawabata T. 1989 Regulatory aspects of marine biotoxins in Japan. In: Natori S, Hashimoto K, Ueno Y, editors. Mycotoxins and Phycotoxins '88. Elsevier, Amsterdam. p. $469-476$

Konovalova GV. 1991. Toxic and potentially toxic dinoflagellates from the far east coastal water of the USSR. In: Smayda TJ, Shimizu Y, editors. Toxic Phytoplankton Blooms in the Sea; Proceedings $5^{\text {th }}$ International conference on Toxic Marine Phytoplankton Newport (USA). Elsevier, Amsterdam. p. $275-279$

Koukaras K, Nikolaidis G. 2002. Intense DSP outbreak associated with a Dinophysis bloom in Thermaikos Gulf (N.W. Aegean Sea, Greece). Harmful Algae News, 23: 8.

Krogh P, Edler L, Graneli E. 1985. Outbreaks of diarrheic shellfish poisoning on the west coast of Sweden. In: Anderson, DM., White, AW. and Baden, DG, editors. Toxic Dinoflagellates. Elsevier, Amsterdam. p. $501-504$.

Kumagai M, Yanagi T, Murata M, Yasumoto T, Kat M, Lassus R, Rodriquez - Vazquez JA. 1986. Okadaic acid as the causative toxin of diarrhoetic shellfish poisoning in Europe. Agric. Biol. Chem., 50, 2853 - 2857.

Madigan TL, Lee KG, Padula DJ, MacNabb P, Pointon AM. 2005. Diarrhetic Shellfish Poisoning Toxin in South Australian Shellfish. Harmful Algae (article in Press).

Mozetic P, Bozic P. 2001. DSP events in Slovenia: A need for legislative regulation. Harmful Algae Management and Mitigation 2001 Abstracts

Morono A, Arevalo F, Fernandez ML, Maneiro J, Pazos Y, Salgado C., Blanco J. 2003. Accumulation and transformation of DSP toxins in mussels Mytilus galloprovincialis 
during a toxic episode caused by Dinophysis acuminata. Aquatic Toxicology 62: 269 -280 .

Murata M, Shimatani M, Sugitani H, Oshima Y, Yasumoto T. 1982. Isolation and structural elucidation of the causative toxin of diarrhetic shellfish poisoning. Bulletin of the Japanese Society of Sciences. Fish 48:549 - 552 .

Papadopoulou - Kyriazi A. Public control and supervision of production Shellfish in the Thermaikos gulf and the administrative limits of prefecture Thessaloniki. Proceedings book Vol. A, $3^{\text {rd }}$ Hellenic Symposium on Food Hygiene and Food Technology, Athens, Greece 2004, $463-466$.

Pavela-Vrancic M, Vestrovic V, Marasova I, Gillman M, Furey A, James KJ. 2002. DSP toxin profile in the coastal waters of Central Adriatic Sea. Toxicon 40: 1601 - 1607.

Ramstad H, Hovgaard P, Yasumoto T, Larsen S, Aune T. 2001. Monthly variations in diarrhetic toxins and yessotoxin in shellfish from coast to the inner part of the Sognefjord, Norway. Toxicon 39: 1035 - 1043.

Rossebo L, Thorson B, Aase R. 1973. Etiologisk uklar matforgifning etter konsum av blaskjell. Norsk. Vet. Tidsskr, 82: $639-642$.

Rossini GP. 2000. Neoplastic activity of DSP toxins: The effects of okadaic acid and related compounds on cell proliferation: Tumor promotion or induction of apoptosis? In: Botana, LM editor. Seafood and freshwater toxins: pharmacology, physiology and detection Marcel Dekker, New York. p. $257-287$

Scoging AC. 1998. Marine biotoxins. Journal of Applied Microbiology, Symposium supplement, $84: 41 S-50 S$.

Scoging AC. Bahl M. 1998. Diarrhetic shellfish poisoning in the UK. Lancet 352: 117.

Sechet V, Safran, P, Hovgaard, P, Yasumoto T. 1990. Causative species of diarrhetic shellfish poisoning (DSP) in Norway. Marine Biology 105: 269 - 274. 
1 Torgersen T, Aasen J, Aune T. 2005. Diarrhetic shellfish poisoning by okadaic acid 2 esters from Brown crabs (Cancer pagurus) in Norway. Toxicon 46:572-578.

3 Underdal B, Yndestad M, Aune T. 1985. DSP intoxications in Norway and Sweden, 4 Autumn 1984 - Spring 1985. In: Anderson DM, White AW, Baden DG, editors. Toxic Dinoflagellates. Elsevier, Amsterdam. p. 489 - 494.

6 Van Egmond HP; Apeldoorn ME van ; Speijers GJA. Marine biotoxins. Rome: Food and 7 Agriculture Organization of the United Nations, 2004 (FAO Food and Nutrition Paper 80)

9 Vale P, Maia AJ, Correia A, Rodrigues SM, Botelho MJ, Casanova G, Silva A, Vilarinho 10 MG, Silva AD. 2003. An outbreak of diarrhetic shellfish poisoning after ingestion of wild mussels at the Northern coast in summer 2002. Electron. Journal Environmental Agricultural and Food Chemistry 2:449 - 452 .

Vale P, Sampayo MAM. 1999. Esters of ocadaic acid and dinophysitoxin-2 in Portuguese bivalves related to human poisonings. Toxicon, 37:1109-1121.

Vale P, Sampayo MAM. 2002. First confirmation of human diarrhoeic poisonings by okadaic acid esters after ingestion of razor clams (Solen marginatus) and green crabs (Carcinus maenas) in Aveiro Lagoon, Portugal and detection of okadaic acid esters in phytoplankton. Toxicon, 40: $511-517$.

Van Dolah F. 2000. Diversity of marine and freshwater algal toxins In: Botana, L. M. editor. Seafood and freshwater toxins: pharmacology, physiology and detection. Marcel Dekker, New York. p. $19-43$.

Van Egmond HP, Aune T, Lassus P, Speijers GJA, Waldock M. 1993. Paralytic and diarrhoeic shellfish poisons, occurrence in Europe, toxicity, analysis and regulation. Journal Natural Toxins 2: 41-83. 
1 Van Egmond HP, Van Apeldoorn ME, Speijers GJA. 2004. "Marine biotoxins". FAO Food And Nutrition Paper 80, Rome.

3 Vieytes M, Louzao MC, Alfonso A., Calbado A G, Botana L. 2000. Mechanism of

4

5 7 10 11 12 13 14 15 16 21 (1) (

action and Toxicology. In: Botana, LM, editor. Seafood and freshwater toxins: pharmacology, physiology and detection. Marcel Dekker, New York. p. $239-256$.

Viviani R, Boni L, Cattani O, Milandri A, Poletti R, Pompei R, Sansoni G. 1995. ASP, DSP, NSP and PSP monitoring in "mucilaginous aggregates" and in mussels in a coastal area of the Northern Adriatic Sea facing Emilia - Romagna in 1988, 1989 and 1991. The Science of Total Environment, 165: 203-211.

Wu JY, Zheng L, Wang JH. 2005. Contamination of shellfish from Shanghai seafood markets with paralytic shellfish poisoning and diarrhetic shellfish poisoning toxins determined by mouse bioassay and HPLC. Food additives and Contaminants 22: 647-651.

Yasumoto T. 2000. Historic considerations regarding seafood safety. In: Botana, LM. editor. Seafood and freshwater toxins: pharmacology, physiology and detection. Marcel Dekker, New York. p. $1-17$.

Yasumoto, T, Murata M, Oshims Y, Matsumoto GK, Clardy J. 1984. Diarrhetic shellfish poisoning. In: Ragelis, E.P., editor. Seafood toxins. AOAC International. Washington DC. p. $214-217$

Yasumoto, T, Murata M, Lee JS, Torigoe K. 1985. Diarrhetic Shellfish toxins. Tetrahedron 41: $1019-1025$.

Yasumoto T, Oshima Y, Sugawara W, Fukuyo Y, Oguri H, Igarishi T, Fujita N. 1980. 23 Identification of Dinophysis fortii as the causative organism of diarrhetic shellfish 24 poisoning. Bulletin of the Japanese Society of Sciences Fish. 46: 1405-1411. 
Table I

\begin{tabular}{|c|c|c|c|c|}
\hline Year/month & Country & $\begin{array}{l}\text { Number } \\
\text { of cases }\end{array}$ & Seafood & Toxins determined \\
\hline 1984 October & Sweden $^{a}$ & $\begin{array}{l}\text { Several } \\
\text { hundred }\end{array}$ & Mussels & $>170 \mathrm{MU} / \mathrm{kg}$ \\
\hline $1984-1985$ & Norway $^{b}$ & $\sim 400$ & Blue mussels & - \\
\hline 1990 August & Canada $^{b}$ & 16 & Mussels & DTX-1: $100 \mu g / 100 g$ \\
\hline 1990 & France $^{c}$ & 415 & $\begin{array}{l}\text { Mussels imported } \\
\text { from Denmark }\end{array}$ & OA: $170 \mu \mathrm{g} / 100 \mathrm{~g}$ \\
\hline 1990 & $\begin{array}{l}\text { Mexico } \\
\text { Gulf }^{d}\end{array}$ & NR & $\begin{array}{l}\text { Oysters } \\
\text { (Crassostrea } \\
\text { virginica) }\end{array}$ & OA: $0.162 \mu \mathrm{g} / 100 \mathrm{~g}$ \\
\hline 1991 January & Chile $^{b}$ & 120 & Mussels & $\begin{array}{l}\text { OA } \\
\text { DTX - } 1\end{array}$ \\
\hline 1991-1994 & Ireland $^{\mathrm{e}}$ & $\begin{array}{l}\text { Several } \\
\text { hundred }\end{array}$ & $\begin{array}{l}\text { Mussels (Mytilus } \\
\text { edulis) }\end{array}$ & $\begin{array}{l}\text { OA: }<0.7 \mu \mathrm{g} / \mathrm{g} \\
\text { DTX-2: } \quad 6.3 \mu \mathrm{g} / \mathrm{g}\end{array}$ \\
\hline
\end{tabular}

OA: 32-151 $\mu \mathrm{g} / 100 \mathrm{~g}$

1993 Summer- 1994

Italy $^{\dagger} \quad \mathrm{NR}$

Mussels $(M$.

Summer

galloprovincialis)

DTX-1: 0-0.32

$\mu g / 100 g$

Donax clams

OA: $130 \mu g / 100 \mathrm{~g}$

1994 February

Portugal $^{g} 18$

(Donax trunculus)

\begin{tabular}{lllll}
\hline 1994 June & UK $^{\mathrm{h}}$ & 2 & Mussels & OA \\
\hline 1997 March & UK $^{\mathrm{i}}$ & 49 & Mussels & OA: 25.3-36.7 \\
& & & & $\mu \mathrm{g} / 100 \mathrm{~g}$ \\
\hline 1997 June & UK $^{\mathrm{j}}$ & 55 & Mussels & -
\end{tabular}




\begin{tabular}{|c|c|c|c|c|}
\hline 1997 February-June & Croatia $^{\mathrm{k}}$ & NR & Mussels & $\begin{array}{l}\text { OA: } 0.133 \mu \mathrm{g} / \mathrm{g} \\
\text { DTX-2: } 0.1 \mu \mathrm{g} / \mathrm{g}\end{array}$ \\
\hline 1997 March-Novembe & Norway' & NR & Blue mussels & OA/DST-1: $349 \mu \mathrm{g}$ \\
\hline 1998 & Slovenia $^{m}$ & $\begin{array}{l}\text { Several } \\
\text { hundred }\end{array}$ & Blue mussels & ND \\
\hline $\begin{array}{l}1998 \text { September- } \\
\text { November }\end{array}$ & Spain $^{\mathrm{n}}$ & NR & Mussels & $\begin{array}{l}\mathrm{OA}: 18-1010 \mu \mathrm{g} \\
/ 100 \mathrm{~g}\end{array}$ \\
\hline 2000 January & Greece $^{\circ}$ & $>120$ & $\begin{array}{l}\text { Mussels (M. } \\
\text { galloprovincialis) }\end{array}$ & ND \\
\hline 2001 June-July & Portugal $^{\mathrm{p}}$ & 7 & $\begin{array}{l}\text { Clams, Razor } \\
\text { clams, Green crabs }\end{array}$ & OA: $32 \mu \mathrm{g} / 100 \mathrm{~g}$ \\
\hline 2002 February & Belgium $^{q}$ & 403 & $\begin{array}{l}\text { Blue mussels } \\
\text { imported from } \\
\text { Denmark }\end{array}$ & OA: $22.9 \mu \mathrm{g} / 100 \mathrm{~g}$ \\
\hline 2002 Summer & Norway ${ }^{r}$ & $\sim 200$ & $\begin{array}{l}\text { Brown crabs } \\
\text { (Cancer pagurus) }\end{array}$ & $\begin{array}{l}\text { OA: } 29 \mu g / 100 g \\
\text { DTX-2: } 2 \mu g / 100 g\end{array}$ \\
\hline 2002 September & Portugal $^{s}$ & 32 & Blue mussels & OA: 1328-1862 \\
\hline $\begin{array}{l}2002 \text { August- } \\
2004 \text { March }\end{array}$ & Denmark $^{t}$ & ${ }^{t} \mathrm{NR}$ & $\begin{array}{l}\text { Surf clams - Blue } \\
\text { mussels }\end{array}$ & $\begin{array}{l}\text { OA: 4.3-163.1 } \\
\mu \mathrm{g} / 100 \mathrm{~g}\end{array}$ \\
\hline 2003 February & Greece $^{\mathrm{u}}$ & NR & $\begin{array}{l}\text { Mussels (M. } \\
\text { galloprovincialis) }\end{array}$ & OA: $0.10-0.20 \mu \mathrm{g} / \mathrm{g}$ \\
\hline 2003 May-October & Chinav $^{v}$ & NR & $\begin{array}{l}\text { Clams, Scallops } \\
\text { Gastropods }\end{array}$ & OA: $3.2-17.5 \mu \mathrm{g} / 100 \mathrm{~g}$ \\
\hline 2003 December & Australia $^{\mathrm{w}}$ & ${ }^{N} \mathrm{NR}$ & Oysters & DSTs total: 0.253 \\
\hline
\end{tabular}




\begin{tabular}{|c|c|c|c|}
\hline & & & $\mathrm{mg} / \mathrm{kg}$ \\
\hline 2004 April & Chile $^{x}$ & Mytilus chilensis & DTX-1:19 $\mu \mathrm{g} / 100 \mathrm{~g}$ \\
\hline
\end{tabular}

$\mathrm{NR}=$ Not Reported, ND=Not Determined, $\mathrm{OA}=$ Okadaic acid, DTX = Dinophysitoxin, DSTs=Diarrhetic Shellfish Toxins

${ }^{a}$ Krogh et al. 1985.

b Aune and Yndestad 1993.

${ }^{c}$ Van Egmond et al. 2004.

${ }^{\mathrm{d}}$ Dickey et al. 1992.

${ }^{\text {e }}$ Carmody et al. 1996

${ }^{\dagger}$ Draisci et al. 1995.

g Vale and Sampayo 1999.

${ }^{\mathrm{h}}$ Anon. 1994.

i Scoging and Bahl 1998.

${ }^{j}$ Anon. 1997.

${ }^{\text {k }}$ Pavela - Vrančič et al. 2002.

' Ramstad et al. 2001.

m Mozetic and Bozic 2001.

${ }^{\mathrm{n}}$ Moroño et al. 2003.

${ }^{\circ}$ Papadopoulou et al. (present study)

p Vale and Sampayo 2002.

${ }^{q}$ De Schrijver et al. 2002.

${ }^{\mathrm{r}}$ Torgersen et al. 2005

${ }^{\text {s }}$ Vale et al. 2003

t Jorgensen et al. 2005. 
${ }^{u}$ Ciminiello et al. 2005

${ }^{\vee}$ Wu et al. 2005

${ }^{\mathrm{w}}$ Madigan et al. 2005

${ }^{\times}$Garcia et al. 2004. 
Table II.

\section{Characteristic}

Values

\section{Demographics}

\begin{tabular}{lc}
\hline Male No. (\%) & $73(60.8)$ \\
\hline Female No. (\%) & $47(39.2)$ \\
\hline Mean age in years (range) & $35(8-70)$ \\
\hline Clinical characteristics &
\end{tabular}

Mean duration of symptoms in $\mathrm{h}$ (range) $\quad 5(0.5-10)$

No. (\%) of patients with DSP symptoms seeking Hospital assistance 120 (100)

Estimated No. of patients with DSP not seeking medical assistance $\quad>500$

\section{Laboratory tests}

No. of patients/no of faecal samples studied

$120 / 120$

No. of mussels' samples bought in the same venders as the cases

during the onset of the outbreak

No. of unconsumed mussels (leftovers) tested

None

No. of mussels' samples bought in the same market as the cases after the end of the outbreak 
TABLE III.

\begin{tabular}{|c|c|c|c|c|c|}
\hline $\begin{array}{l}\text { Sampling } \\
\text { Date }\end{array}$ & $\begin{array}{c}\text { Place } \\
\text { (one sample/place) }\end{array}$ & Symptoms observed & $\begin{array}{r}\text { Median Mou } \\
\text { (number of mi } \\
\text { mice }\end{array}$ & $\begin{array}{l}\text { al Time } \\
\text { lumber of }\end{array}$ & $\begin{array}{l}\text { DSP toxins } \\
\text { Result }\end{array}$ \\
\hline $\begin{array}{l}\text { Outbreak } \\
15 / 1 / 2000\end{array}$ & Thermaikos Gulf & $\begin{array}{l}\text { Apathy, weakness, difficulty in movement, respiratory } \\
\text { distress, spastic contractions just before death }\end{array}$ & $1 \mathrm{~h} 25 \mathrm{~min}$ & $(3 / 3)$ & Positive \\
\hline $\begin{array}{l}\text { Outbreak } \\
19 / 1 / 2000\end{array}$ & Thermaikos Gulf & $\begin{array}{l}\text { Apathy, weakness, difficulty in movement, respiratory } \\
\text { distress, spastic contractions just before death }\end{array}$ & $1 \mathrm{~h} 30 \mathrm{~min}$ & $(3 / 3)$ & Positive \\
\hline $15 / 4 / 2000$ & Thermaikos Gulf & No symptoms & $>48 \mathrm{~h}$ & $(0 / 3)$ & Negative \\
\hline $6 / 12 / 2000$ & Thermaikos Gulf & No symptoms & $>48 \mathrm{~h}$ & $(0 / 3)$ & Negative \\
\hline $19 / 1 / 2001$ & Amvrakikos gulf & $\begin{array}{l}\text { Apathy, weakness, difficulty in movement, } \\
\text { hypersensitivity, respiratory distress }\end{array}$ & $9 \mathrm{~h}$ & $(3 / 3)$ & Positive \\
\hline 22/2/2001 & $\begin{array}{l}\text { Thermaikos Gulf } \\
\text { Amvrakikos gulf }\end{array}$ & No symptoms & $>48 \mathrm{~h}$ & $(0 / 3)$ & Negative \\
\hline $23 / 3 / 2001$ & Thermaikos Gulf & $\begin{array}{c}\text { Apathy, weakness, difficulty in movement, respiratory } \\
\text { distress }\end{array}$ & $5 \mathrm{~h}$ & $(3 / 3)$ & Positive \\
\hline $10 / 9 / 2001$ & $\begin{array}{l}\text { Thermaikos Gulf } \\
\text { Amvrakikos gulf }\end{array}$ & No symptoms & $>48 \mathrm{~h}$ & $(0 / 3)$ & Negative \\
\hline $20 / 12 / 2001$ & Thermaikos Gulf & No symptoms & $>48 \mathrm{~h}$ & $(0 / 3)$ & Negative \\
\hline
\end{tabular}




\section{Page 27 of 28}

Food Additives and Contaminants

\begin{tabular}{lllll}
\hline \multicolumn{3}{c}{ Amvrakikos gulf } & & \\
\hline $15 / 4 / 2002$ & Thermaikos Gulf & No symptoms & $>48 \mathrm{~h}$ & $(0 / 3)$ \\
\hline $20 / 7 / 2002-$ & Thermaikos Gulf & No symptoms & $>48 \mathrm{~h}$ & $(0 / 3)$ \\
$20 / 7 / 2005$ & Amvrakikos gulf & & $(0 / 3)$ & \\
\hline
\end{tabular}




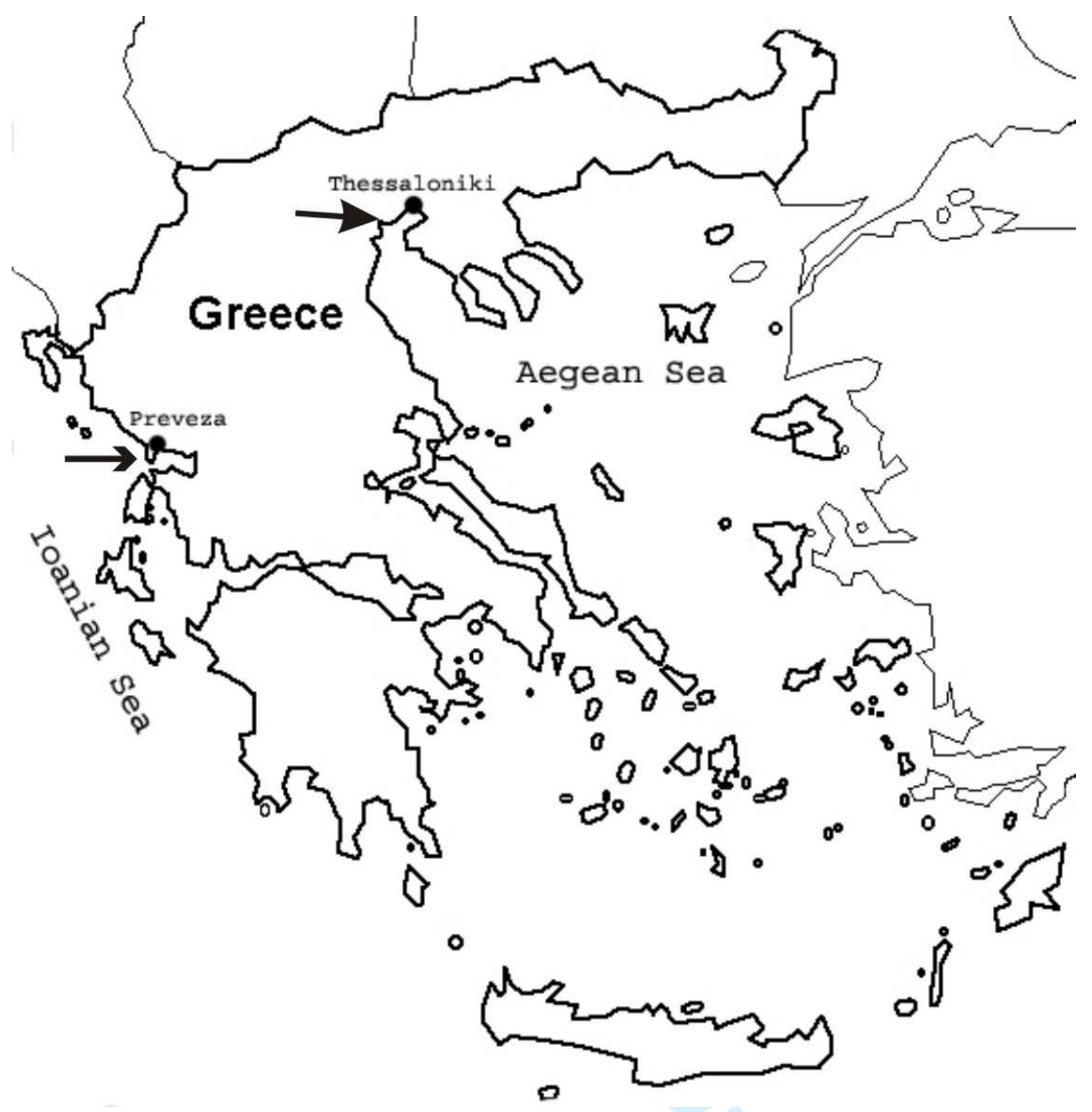

FIGURE 1. 